\title{
Ras Peptide
}

National Cancer Institute

\section{Source}

National Cancer Institute. Ras Peptide. NCI Thesaurus. Code C94613.

A peptide which has an amino acid sequence that is identical to a portion of a protein that

is in the Ras subfamily of small GT Pases. 